\title{
Return to Normal Streamflows and Water Levels: Summary of Hydrologic Conditions in Georgia, 2013
}

The U.S. Geological Survey (USGS) South Atlantic Water Science Center (SAWSC) Georgia office, in cooperation with local, State, and other Federal agencies, maintains a long-term hydrologic monitoring network of more than 340 real-time continuous-record streamflow-gaging stations (streamgages), including 10 real-time lake-level monitoring stations, 67 real-time surface-water-quality monitors, and several water-quality sampling programs. Additionally, the SAWSC Georgia office operates more than 180 groundwater monitoring wells, 39 of which are real-time. The wide-ranging coverage of streamflow, reservoir, and groundwater monitoring sites allows for a comprehensive view of hydrologic conditions across the State. One of the many benefits of this monitoring network is that the analyses of the data provide a spatially distributed overview of the hydrologic conditions of creeks, rivers, reservoirs, and aquifers in Georgia.

Streamflow and groundwater data are verified throughout the year by USGS hydrographers. Hydrologic conditions are determined by comparing the results of statistical analyses of the data collected during the current water year ${ }^{1}$ (WY) to historical data collected over the period of record. Changing hydrologic conditions emphasize the need for accurate, timely data to help Federal, State, and local officials make informed decisions regarding the management and conservation of Georgia's water resources for agricultural, recreational, ecological, and water-supply needs and for use in protecting life and property.

Drought conditions, persistent in the area since 2010, continued into the 2013 WY. In February 2013, Georgia was free of extreme (D3) drought conditions, as defined by the U.S. Drought Monitor, for the first time since August 2010 due to extended periods of heavy rainfall (U.S. Drought Monitor, 2013). According to the Office of the State Climatologist, the city of Savannah recorded 9.75 inches of rain in February 2013, the highest monthly total in February out of 143 years of record. Macon and Columbus also received record rainfalls in February 2013. Abovenormal precipitation continued in June 2013, and the cities of Augusta and Savannah recorded the wettest June on record. In July, precipitation for the entire State of Georgia was 3.53 inches above normal (Dunkley, 2013). Above-normal rainfall from February to September 2013 increased streamflow and raised groundwater levels, and lakes and reservoirs were raised to full-pool elevations.
Quarterly Hydrologic Conditions in Georgia for 2013 WY, Based on Drainage Basin Runoff
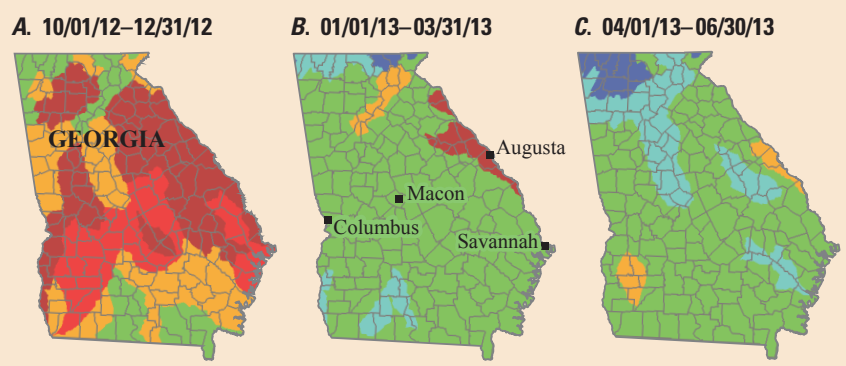

These maps represent hydrologic conditions during the 2013 WY compared to available historical data. Runoff, or flow per unit area, is a good indicator of precipitation and streamflow conditions for a given basin (Langbein and Iseri, 1960). Runoff was calculated for each basin and is presented uniformly over the entire basin area. Only streamflow stations with a complete daily-flow dataset for the $2013 \mathrm{WY}$ were used (U.S. Geological Survey, 2013c). For the first quarter of the 2013 WY (October-December 2012, fig. 2A), the majority of the State was observing "below normal" (10 to 24 percentile class), "much below normal" (less than 10 percentile class), and "lowest" runoff conditions. During the second quarter of the 2013 WY (January-March 2013, fig. 2B), the majority of the State received above-normal precipitation, and runoff conditions returned to normal $(25$ to 75 percentile class) for the majority of the State. During the fourth quarter (July-September 2013, fig. 2D), runoff conditions in the majority of the State were "above normal" (76 to 90 percentile class), "much above normal" (greater than 90 percentile class), and "highest" on record.

\section{7/01/13-09/30/13}

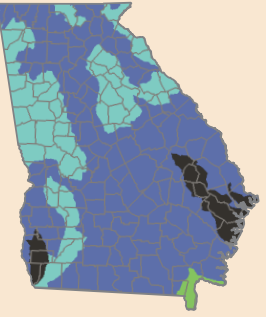

EXPLANATION Percentile classes

Highest Above normal, 76 to 90 Normal, 25 to 75 Below normal, 10 to 24 Lowest

\section{Water Resources Internet Tools}

Historically, hydrologic data collected by the USGS were compiled into annual data reports; however, this method of publication has been discontinued. Current and historical data are now available through the National Water Information System Web interface, or NWISWeb, at http://waterdata.usgs.gov/nwis (U.S. Geological Survey, 2013a).

The USGS has several water resources Internet tools designed to provide users with current streamflow and groundwater data, flood inundation maps, stream statistics, and water-quality information (U.S. Geological Survey, 2013b). Two of these Internet tools are WaterNow and WaterAlert. WaterNow, available at http://water.usgs.gov/waternow/, allows users to request current data for a USGS site by using a mobile phone through text messaging or by email. WaterAlert, available at http:/ water.usgs.gov/wateralert/, will notify a user by text message or email when a user-defined threshold is exceeded at a real-time USGS site.

Selected USGS Water Resources Internet Tools USGS National Water Information System (NWIS) http://waterdata.usgs.gov/nwis

Much above normal, $>90$ Much below normal $<10$

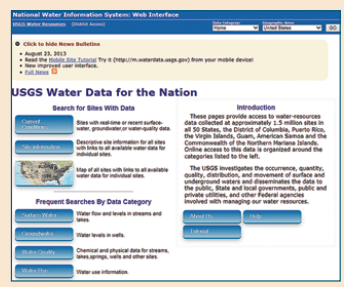

SGS WaterNow

http://water.usgs.gov/waternow/

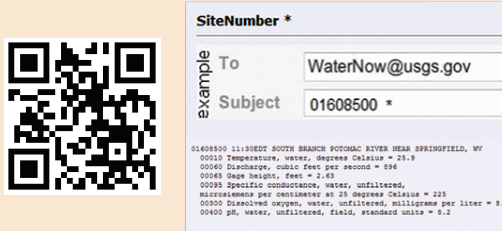

USGS WaterAlert

http://water.usgs.gov/wateralert/

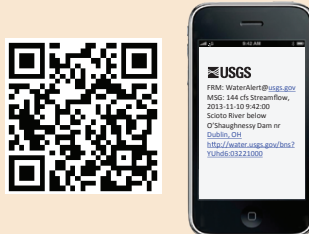

(From U.S Geological Survey, 2013b) 


\section{Chattooga River at Summerville, Ga. 02398000}

The Chattooga River flows from the northwestern corner of Georgia, in the Blue Ridge Physiographic Province, int Alabama where it flows into Weiss Lake (U.S. Geological Survey, 1975). For the majority of the 2013 WY, 7 -day average streamflow conditions were "normal" to "much above normal." Daily discharge for most of the 2013 WY was in the maximum range. New record high daily discharges were observed in January, A
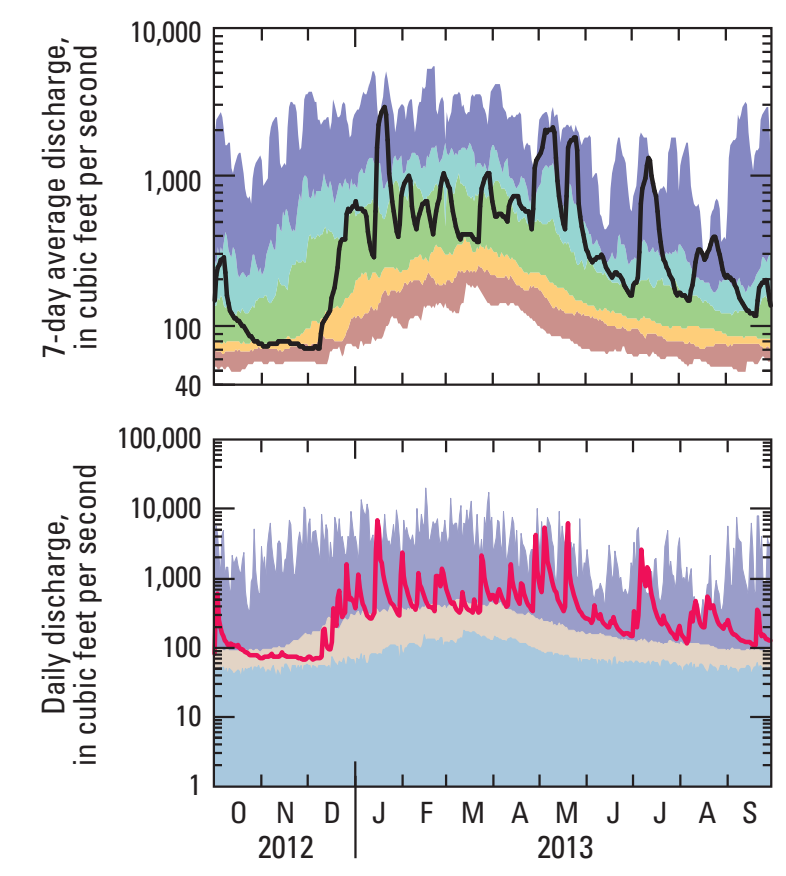

\section{Ocmulgee River at Macon, Ga. 02213000}

The Ocmulgee River flows out of Jackson Lake and joins the Oconee River to form the Altamaha River in the Coastal Plain Physiographic Province in central Georgia (U.S. Geologica Survey, 1975). At the start of the $2013 \mathrm{WY}$, streamflows were approaching a new record low. Starting in December 2012, daily discharge increased and fluctuated between the "median "and "maximum" ranges of historical daily mean flow. In February 2013, the 7-day average discharge was mostly "normal," with several normal" flows.
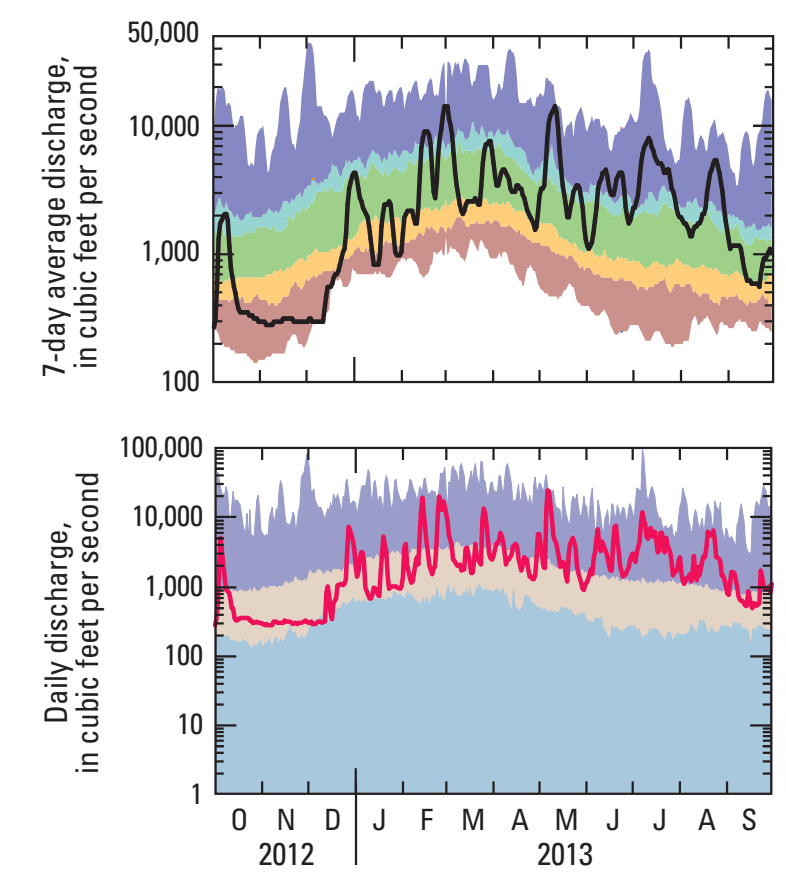

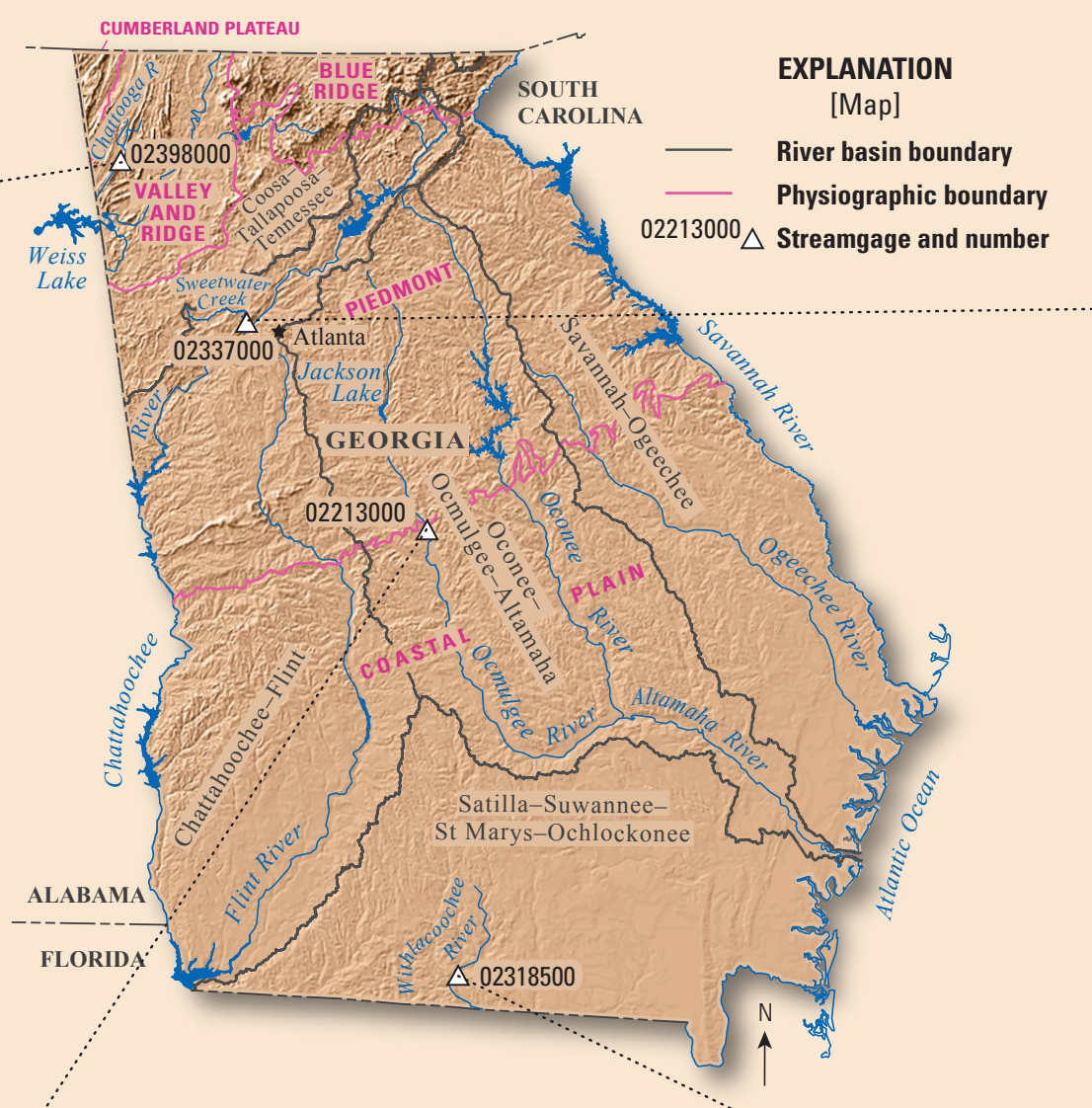

\section{EXPLANATION}

7-Day Average Discharge

Hydrographs show the 7-day average discharge for 2013 as compared to 7. Data are categorized in perconte ranges from "much above normal" (greater than the 90th percentile) to "much below "

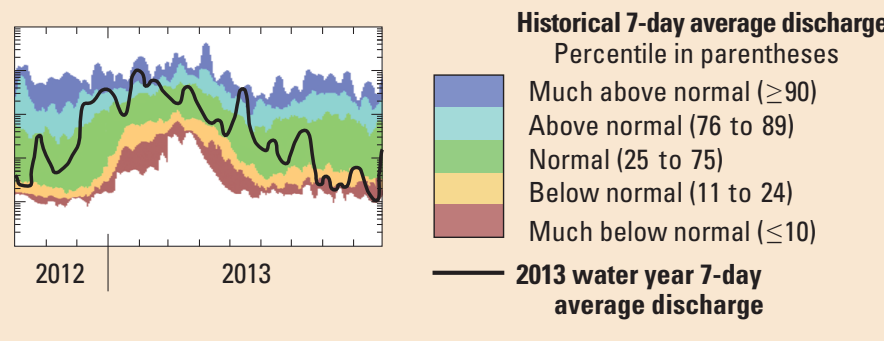

Daily Discharge

Hydrographs show 2013 daily-mean discharge, in cubic feet per second, as 政 of record (U.S. Geological Survey, 2013a).

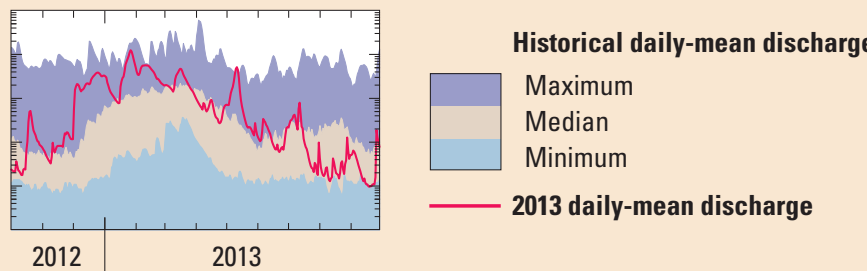

Sweetwater Creek near Austell, Ga 02337000

Sweetwater Creek is a major tribuary of the Chattahoochee River the Piedmont Physiographic Province (U.S. Geological Survey, 1975). For the firs half of the $2013 \mathrm{WY}$, 7-day average streamtlow conditions were "below normal" to "much below normal," and record low 7-day
average streamflows were observed in November and December. Steady precipitation in the area, stanting in December, brought in much needed rainfall, and the 7 -day mostly between "normal" and "much above normal" for the rest of 2013 Wy New minimum daily mean discharges were observed in October, November, and December, followed by streamflows in the "median" and "maximum" ranges for the remainder of the $2013 \mathrm{WY}$
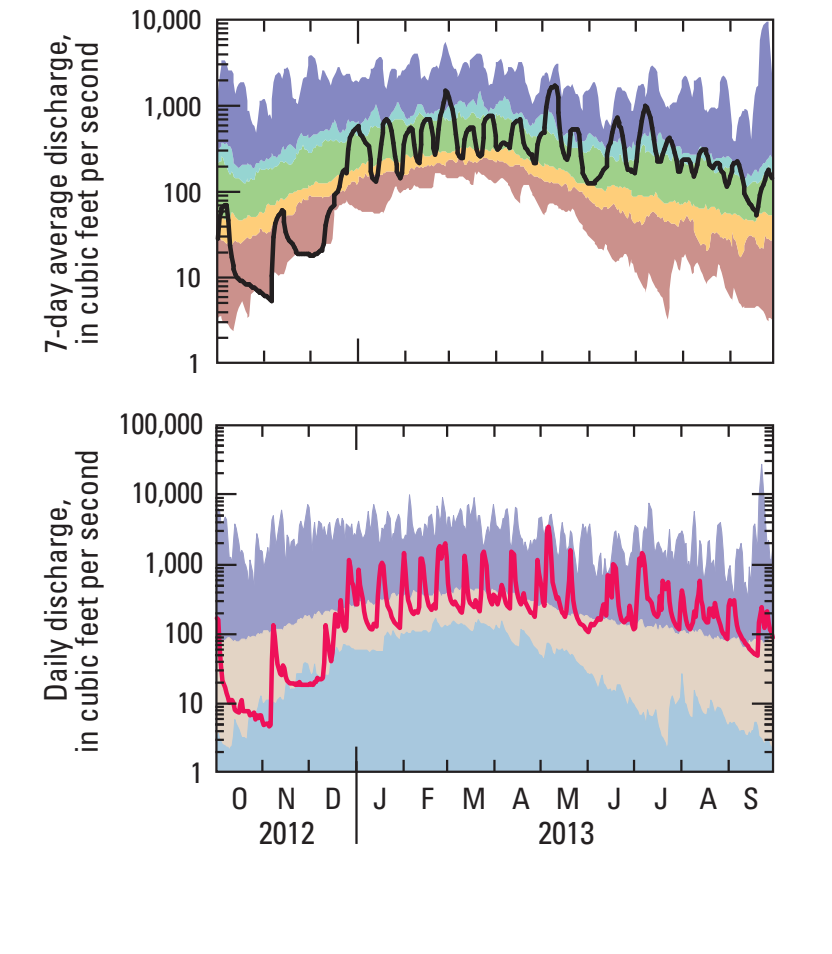

\section{Withlacoochee River at US 84 near Ouitman, Ga. 02318500}

The Withlacoochee River flows in the Suwannee River Basin in the southern coastal plain of Georgia (U.S. Geological Survey, 1975). For much of the 2013 WY, 7-day average streamflow conditions were "normal" to "much above normal," and record-high 7-day average streamflows were observed during March, July, and August. Daily discharge was mostly in the "maximum" range from February to September. New maximum daily-mean discharges were recorded during February
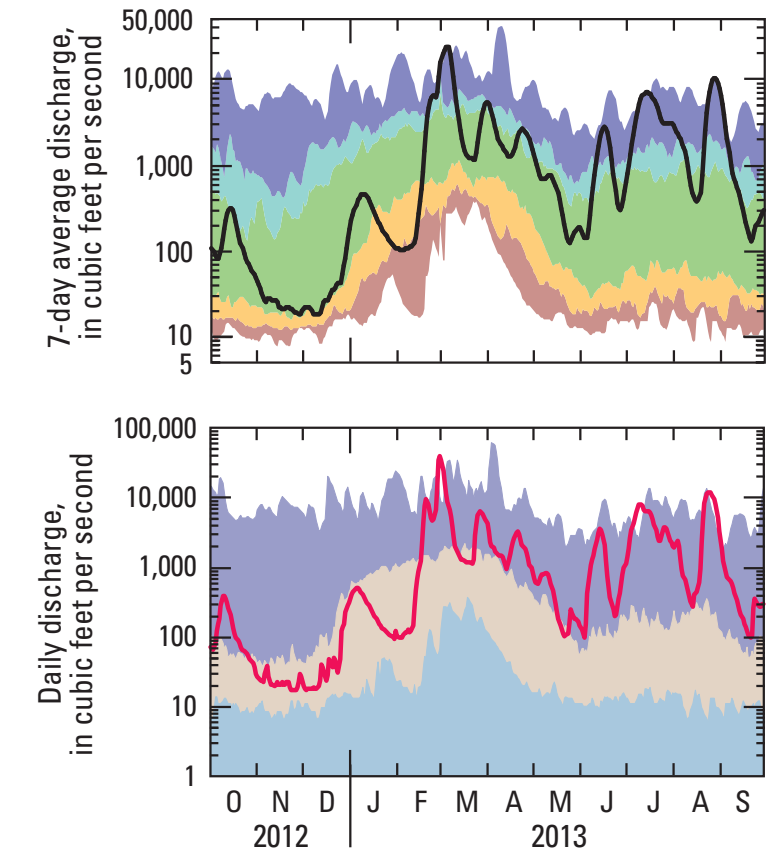


\section{Climate Response Network}

The USGS maintains a network of groundwater wells to monitor the effects of droughts and other climate variability on groundwater evels. These wells are part of the Climale Response Network, which is designed to measure the effects of cl Geological Survey, 2007, 2013d). The national network core pumping or other human influcnces af 15 are loceted in Georgia These wells are monitored as part of the USGS Groundwater Resources and Cooperative Water Programs. Current conditions of groundwater wells in the Climate Response Network can be accessed online at http.//groundwaterwatch usgs gov/. The hydrographs presented in figure 4 are for selected wells in Georgia having at least 5 years of continuous data.

\section{OUSGS}

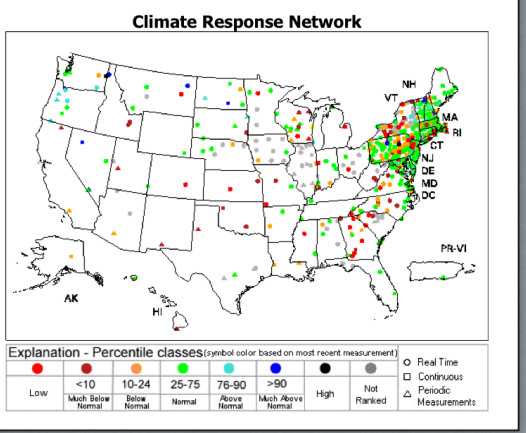

U. Climate Response Network can be accessed online at http://groundwaterwatch. usgs.gov/

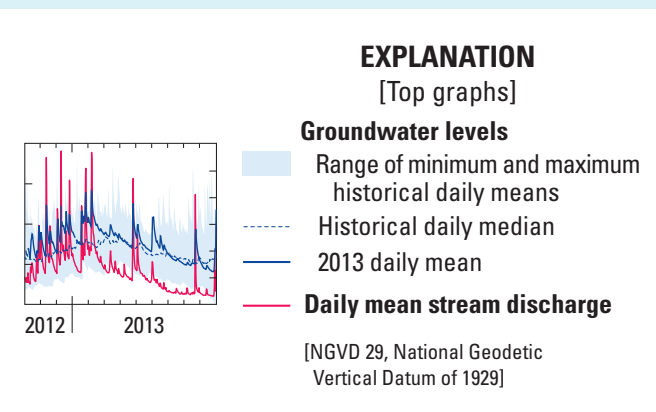

Well $07 \mathrm{H} 003$ is in Miller County in southwestern Georgia and is completed in the surficial aquifer, which is an unconfined aquifer in this area (Peck and others, 2013). Water levels in this well generally rise rapidly during wet periods and decline slowly during dry periods. The water level in well 07 H003 responds to seasonal change similarly to streamflow at the nearby streamgage on Spring Creek near Iron City, Ga. (02357000), which indicates atmospheric, surface-water, and groundwater interactions. The water level in well $07 \mathrm{H} 003$ was below the historical daily median at the start of the $2013 \mathrm{WY}$ until February when the area received more than 10 inches of precipitation for the month and the water level rose 14 feet and was above the historical daily median. The water level slowly declined below the historical daily median from Marc through June. New maximum daily mean water levels were recorded during the months of July and August after the area received more than 13 and 9
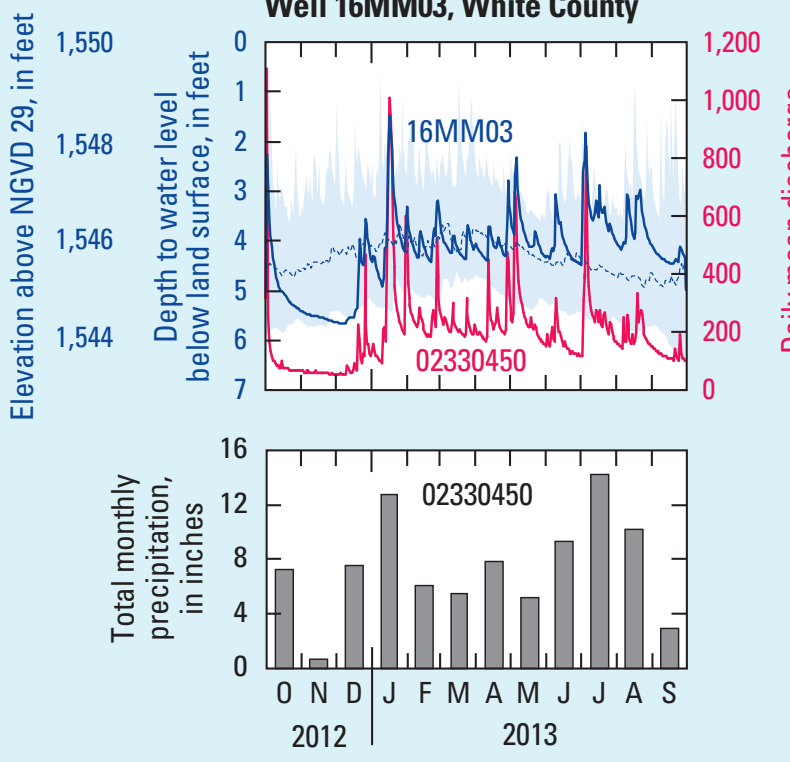

Well 35P094, Chatham County
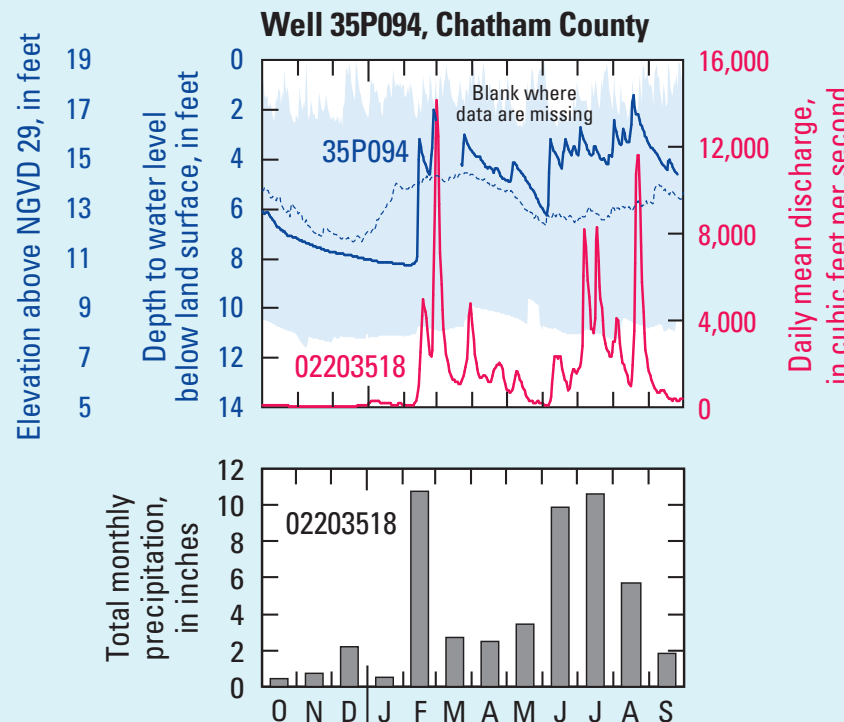

2012

2013
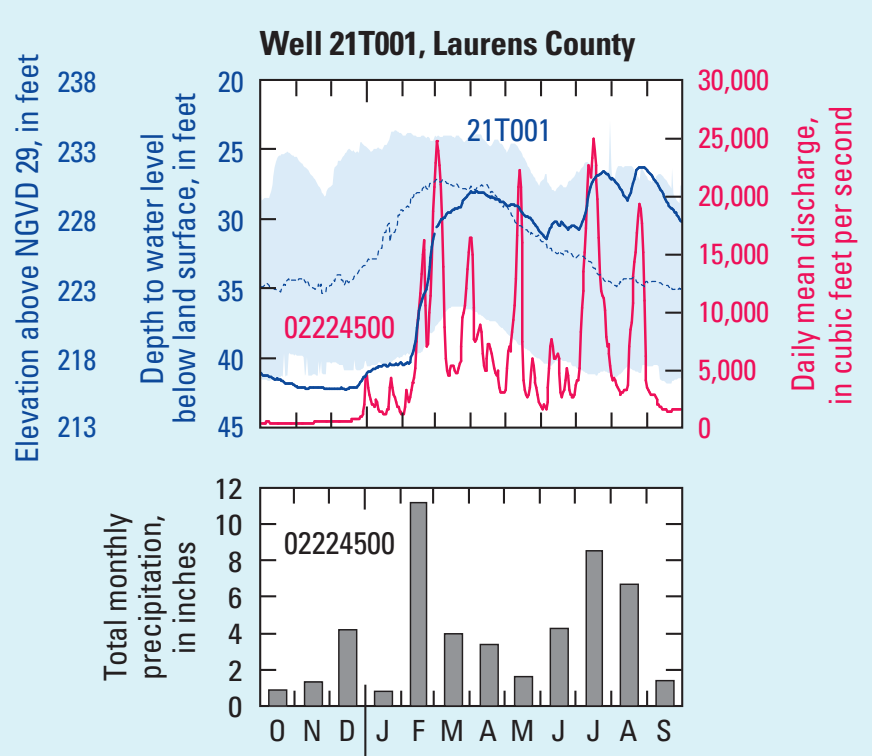

ON D
Well 16MM03 is in White County in northeastern Georgia and is completed in the crystalline-rock aquifer. Water is stored in the regolith and fractures, and the water level is affected by precipitation and evapotranspiration (Cressler and others, 1983). Precipitation can cause a rapid water-level rise in wells tapping aquifers overlain by thin regolith (Peck and others, 2013). The water level in well 16MM03 responds to seasonal change similarly to streamflow at the nearby streamgage on the Chattahoochee River at Helen, Ga. (02330450), which indicates atmospheric, surface-water, and groundwater interactions. As the drought continued into the $2013 \mathrm{WY}$, new minimum daily mean water levels, approximately 5.5 feet below land surface, were recorded at the end of November and beginning of December. In December and January, the area received more than 7 and 12 inches of precipitation, respectively, and the water level in well 1 Mistorica from 15 to 25 foel January, April, May, June, and July.

Well 35 P094 is in Chatham County in southeastern Georgia and is completed in the surficial aquifer. Water levels generally rise rapidly during wet periods and decline slowly during dry periods. The water level in well 35P094 responds to seasonal change similarly to streamflow at the nearby streamgage on the Canoochee River at Bridge 38, at Fort Stewart, Ga. (02203518), which indicates atmospheric, surface-water, and groundwater interactions. The water level in well 35 P094 was the start of the 2013 WY. In February, the area received more than 10 inches of precipitation for the month, and the water levels rose nearly 6 feet, remaining above the historical daily median through the end of the WY.

Well 21T001 is in Laurens County in east-central Georgia and aquifer, which is an unconfined aquifer in this area. Water levels in semiconfined areas of the Upper Floridan aquifer fluctuate seasonally in response to variations in precipitation, evapotranspiration, and natural drainage or discharge (Peck and others, 2013). The water level in well 21 T001 responds to seasona change similarly to streamflow at the nearby streamgage on Oconee River near Mount Vernon, Ga. (02224500), which indicates atmospheric, surface-water, and groundwater interactions. In the $2013 \mathrm{~W}$, well 21001 rocod new minimum daily median February In Febre recipitation, and the water level in well 217001 rose from 40 31 feet below and surface and was above the historical dily median from May through the remainder of the water $y$. In July, August, and September, new maximum daily mean water. In July, were recorded after the area received more than 8 inches of precipitation in July and nearly 7 inches in August. 
Discrete and Continuous Water-Quality Conditions in Georgia

Water-quantity and quality information are both importan for ensuring adequate water availability for human consumption, industrial uses, and aquatic ecosystems. Water-quality conditions
are related strongly to water quantity. Precipitation and streamflow conditions are primary agents of delivery and transport of both and others, 2006).

\section{Ceorgia Environmental Protection Division}

The USGS provides the Georgia Department of Natural Resources Environmental Protection Division (GaEPD) and the term water-quality data which assists the GaPPD in meeting responsibilities under the Clean Water Act. The USGS-GaEPD discrete water-quality sampling program is designed to collect data systematically, regardless of hydrologic conditions. Waterquality data for Georgia streams are available to the public at

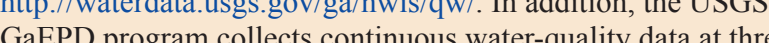
sites, including the Chattahoochee River near Fairburn, Ga

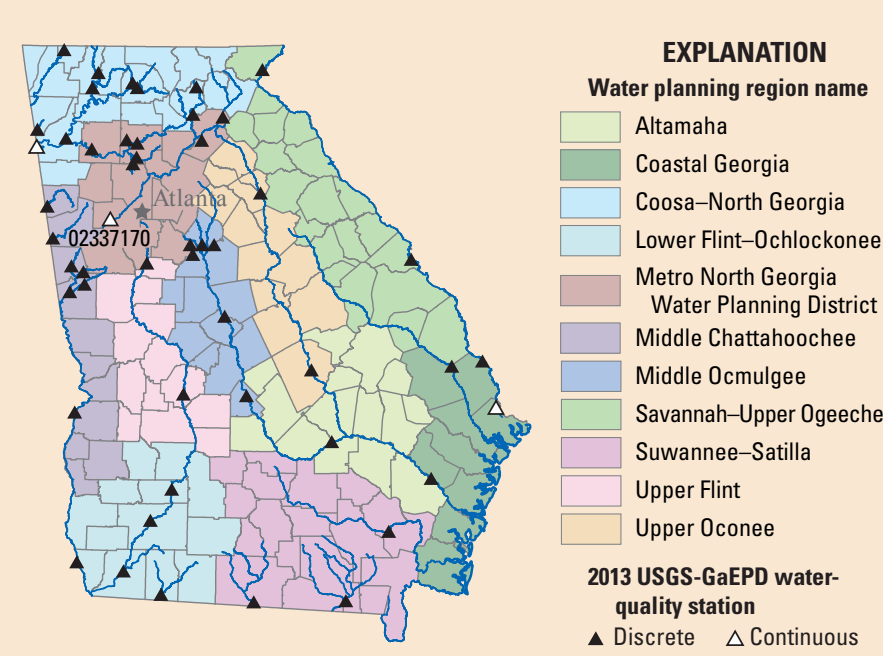

\section{Chattahoochee River near Fairburn, Ga. 0233717} just south of Atlanta in the Metro North Georgia Water Planning Distric planning region, has a drainage area of 2,060 square iles. Water use for his stream reach is classified as "fishing" under Georgia Code 391-3-6-.03, which to or grester the 50 mithsolved oxygen concont Resources, 2013). No daily mean dissolved oxygen level fell below -

the "fishing" criteria at station 02337170 during the 2013 WY (graph below).

\section{Urban Water-Quality Program}

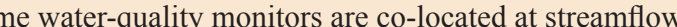
stations around the Atlanta metropolitan area: Gwinnett County (15), Fulton County (8), Dekalb County (15), and Douglas County (1). These water-quality monitors collect water-temperature, specific-conductance, and turbidity datas in addition, several monitors collect pH and dissolved oxygen data. Some of dissolved constituents Turbidity can be used as a surrogate for suspended sediment as well as other constituents that adhere to suspended-sediment particles, such as heavy metals, pesticides, and fecal coliform. Relating

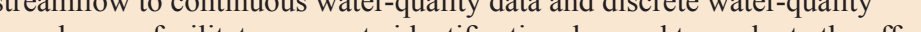
of watershed characteristics on contituent concentrations and determine water-qulity trends. Data hike these are summarized in scientific investigations reports, such as Watershed Characteristics and Water-Quality Trends and Loads in 12 Watersheds in Gwinnett County, Georgia (Joiner and others, 2014).

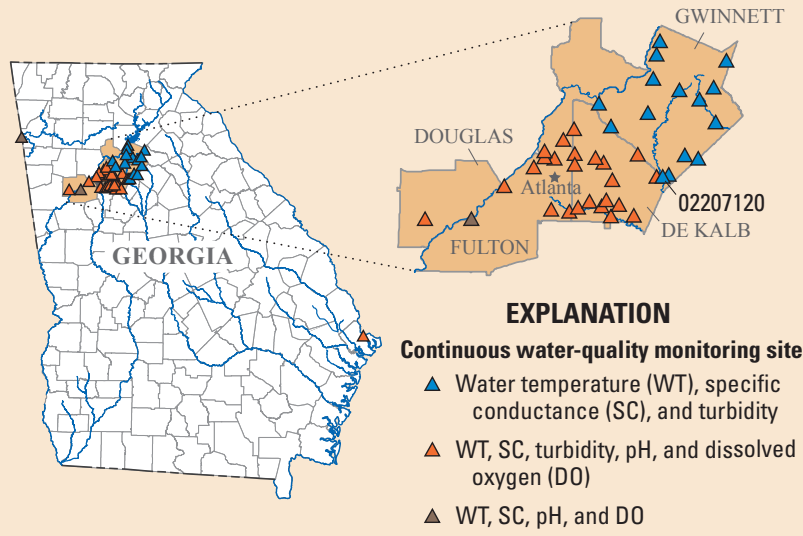
02337170 Chattahoochee River near Fairburn, $G$

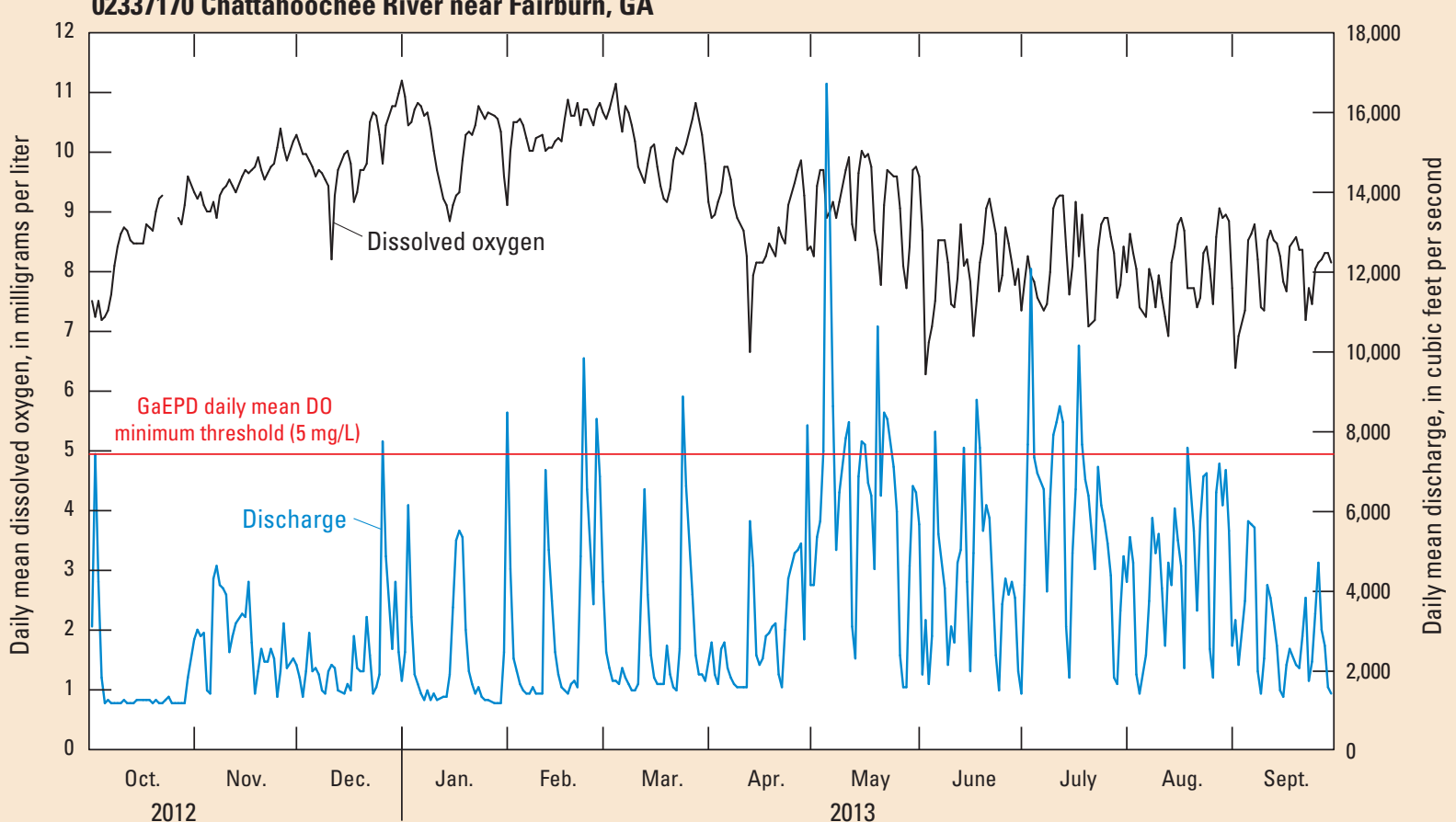

\section{Yellow River at GA 124 near Lithonia, Ga. 02207120}

Yellow River station 02207120, located in Gwinnett County, measured, and 10 total suspended solids (TSS) samples were collected, 7 during stormflow and 3 during base flow. Turbidity is a measure of water clarity and light reflected off particles in streamflo caused by clay, silt, and fine suspended inorganic and organic matter flow conditions. Chronic levels of suspended materials in streams are often the cause of stream impairment (U.S. Environmental Protection Agency, 2012). TSS concentrations and turbidity levels were
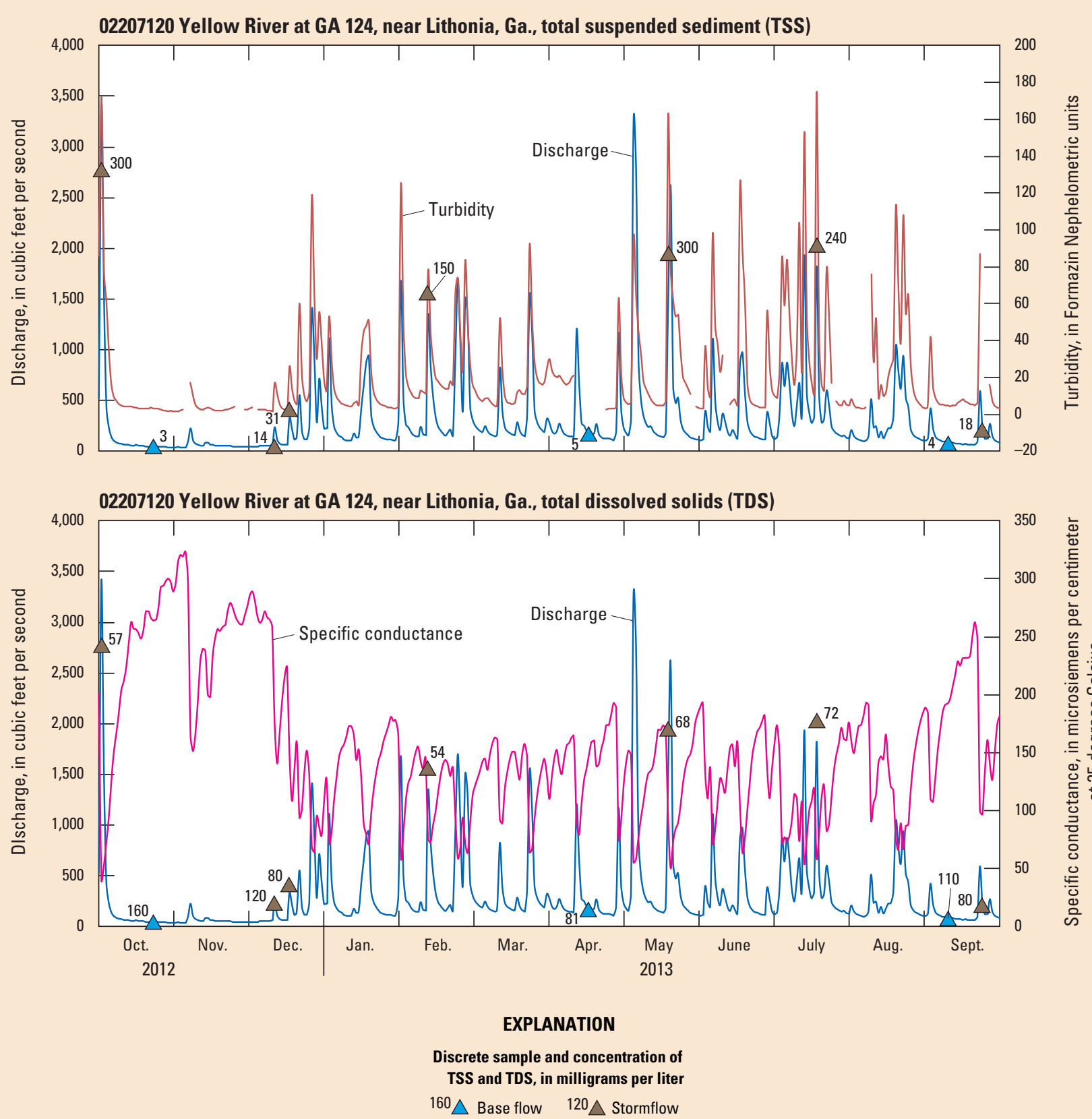


\section{Lakes and Reservoirs}

Major lakes and reservoirs throughout Georgia are managed primarily by the U.S. Army Corps of Engineers and Georgia Power Company to provide water for public and industrial use, flood protection, power generation, wildlife management, and recreation. To manage lakes and reservoirs, tools such as computer models that rely on real-time USGS streamflow data help to predict changes in climatic conditions and water demands.

Lake Sidney Lanier on the Chattahoochee River is the primary drinking-water source for much of Metropolitan Atlanta. Lake Sidney Lanier is the farthest upstream reservoir in a series of reservoirs that include West Point Lake, Walter F. George Lake, and Lake Seminole. On December 23, 2012, Lake Sidney Lanier reached the 2013 WY minimum elevation of 1,056.33 feet. From January to April 2013, the inflow was 3.6 times greater

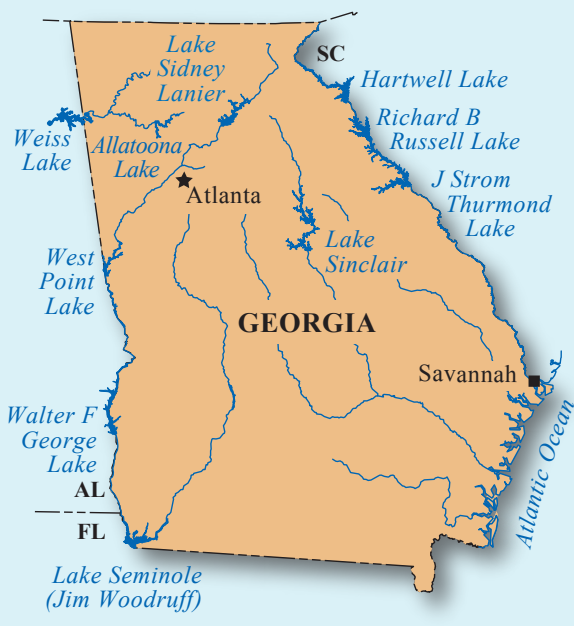

\section{References Cited}

Cressler, C.W., Thurmond, C.J., and Hester, W.G., 1983, Groundwater in the greater Atlanta region, Georgia: Georgia Geological Survey Information Circular 63, 15 p.

Dunkley, N., 2013, 2013 Climate summaries: Georgia Department of Natural Resources, Environmental Protection Division, accessed August 14, 2014, at https://epd.georgia.gov/office-state-climatologist.

Georgia Department of Natural Resources, Environmental Protection Division, 2013, Existing rules and corresponding laws, 391-3-6 Water quality control, accessed July 16, 2013, at https://epd. georgia.gov/georgia-water-quality-standards.

Hirsch, R.M., Hamilton, P.A., and Miller, T.L., 2006, U.S. Geological Survey perspective on waterquality monitoring and assessment: Journal of Environmental Monitoring, v. 8, p. 512-518.

Joiner, J.K., Aulenbach, B.T., and Landers, M.N., 2014, Watershed characteristics and waterquality trends and loads in 12 watersheds in Gwinnett County, Georgia: U.S. Geological Survey Scientific Investigations Report 2014-5141, 79 p., accessed February 27, 2015, at http://dx.doi.org/10.3133/sir20145141.

Langbein, W.B., and Iseri, K.T., 1960, General introduction and hydrologic definitions: U.S Geological Survey Water-Supply Paper 1541-A, 29 p. than the outflow, and the lake level increased nearly 16 feet to a fullpool elevation of $1,072.24$ feet, and remained near full pool for the remainder of the 2013 WY.

West Point Dam provides flood protection and hydroelectric power to Troup County. The water-level elevation of West Point Lake at the start of the 2013 WY was approximately 10 feet below full pool. From December 2012 to January 2013 , the water level was raised 13 feet to maintain a level near the top of conservation pool for the remainder of the water year.

Allatoona Lake is on the Etowah River and is managed by the U.S. Army Corps of Engineers. During the 2013 WY, the water level of Allatoona Lake remained above or just below the top of conservation pool.

Hartwell Lake is the most upstream major reservoir on the Savannah River in a series of reservoirs that include Richard B. Russell and J. Strom Thurmond Lakes. These three lakes on the Savannah River are managed by the U.S. Army Corps of Engineers for water supply, power generation, and water-quality needs of the Savannah River from below Thurmond Dam to Savannah, Georgia, and the Atlantic Ocean (U.S. Army Corps of Engineers, 2013a). During the 2013 WY, Hartwell Lake reached a minimum elevation of 644.77 feet on December 15, 2012. Between January and April 2013, the inflow was 2 times greater than outflow, and the lake level increased more than 20 feet to a full-pool elevation of 664.79 feet. The water-level elevation remained near full pool for the remainder of the $2013 \mathrm{WY}$.

Peck, M.F., Gordon, D.W., and Painter, J.A., 2013, Groundwater conditions in Georgia, 2010-2011: U.S. Geological Survey Scientific Investigations Report 2013-5084, 63 p. (Also available at http://pubs.usgs.gov/sir/2013/5084/.)

U.S. Army Corps of Engineers, 2013a, Hartwell Dam and Lake: U.S. Army Corps of Engineers, Savannah District, accessed June 1, 2013, at http://www. sas.usace.army.mil/About/DivisionsandOffices/ OperationsDivision/HartwellDamandLake.aspx.

U.S. Army Corps of Engineers, 2013b, Lake elevations, inflows and outflows, accessed June 1, 2013, at http://www.sas.usace.army.mil/.

U.S. Drought Monitor, 2013, U.S. Drought Monitor maps and data, accessed July 1, 2014, at http://droughtmonitor.unl.edu/MapsAndData/ DataTables.aspx?southeast.

U.S. Environmental Protection Agency, 2012, Georgia water quality assessment report, Georgia cumulative TMDLs by pollutant, accessed July 1, 2014, at http://ofmpub.epa.gov/waters $10 /$ attains_state.control?p_state $=\mathrm{GA}$.

U.S. Geological Survey, 1975, Hydrologic unit map-1974, State of Georgia: U.S. Geological Survey, scale 1:500,000, 1 sheet.

U.S. Geological Survey, 2007, U.S. Geological Survey ground-water Climate Response Network: U.S. Geological Survey Fact Sheet 2007-3003, 4 p., accessed July 1, 2009, at http://pubs.usgs.gov/fs/2007/3003/.

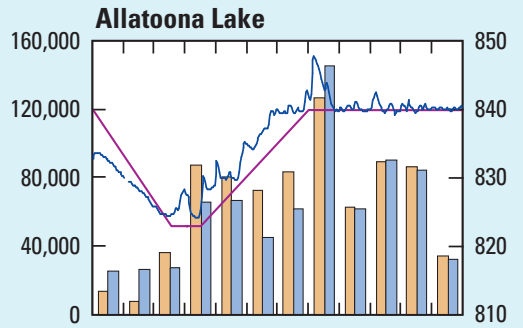

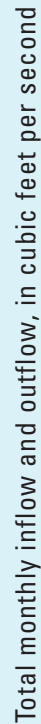

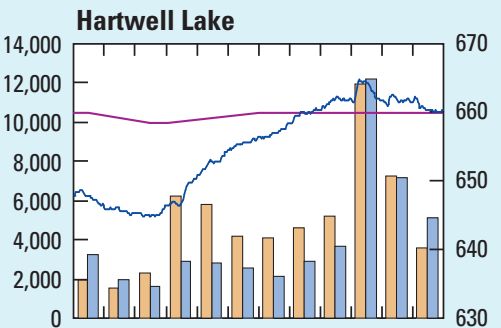

Lake Sidney Lanier

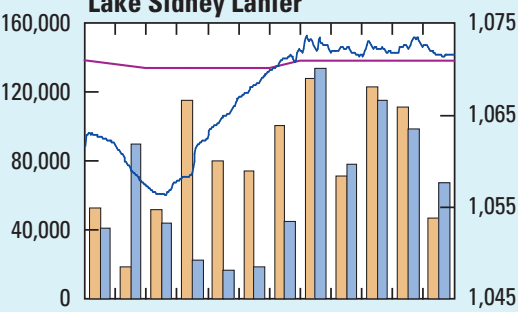

West Point Lake

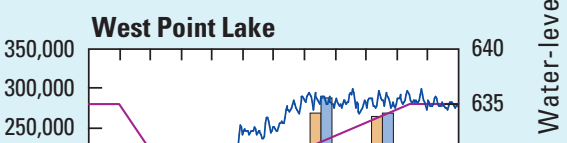

U.S. Geological Survey, 2013a, National Water Information System: Web Interface, accessed July 1, 2014, at http://waterdata.usgs.gov/nwis.

U.S. Geological Survey, 2013b, U.S. Geological Survey water resources Internet tools: U.S. Geological Survey Fact Sheet 2013-3072, 2 p. accessed July 1, 2014, at http://pubs.usgs.gov/ fs $/ 2013 / 3072 /$

U.S. Geological Survey, 2013c, WaterWatchCurrent water resources in Georgia, accessed July 1, 2011, at http://waterwatch.usgs.gov/.

U.S. Geological Survey, 2013d, USGS groundwater watch, Climate Response Network, accessed July 1, 2014, at http://groundwaterwatch.usgs.gov/.

\section{By Andrew E. Knaak, Kerry Caslow, and Michael F. Peck}

For more information contact:

Director, USGS South Atlantic Water

Science Center, Georgia

1770 Corporate Drive

Norcross, Georgia

(770) 624-6700

http://ga.water.usgs.gov/

Water year is the period October 1 through September 30 and is designated by the year in which it ends. For example, the 2013 water year began on October 1, 2012, and ended on September 30, 2013. 